\title{
Articles
}

\section{The Post Always Rings Twice: The Postmodern and the Postcolonial}

\author{
LINDA HuTCHEON
}

Résumé

Il s'agit désormais d'une vérité de la théorie culturelle : si les termes postmodernisme et postcolonialisme ont évidemment plus en commun que leur préfixe, les grandes entités culturelles qu'ils en sont venus à désigner ne sont aucunement identiques. Cette analyse critique détaillée d'un cas qui a donné lieu à une polémique l'exposition Into the Heart of Africa de 1989-1990 au Musée royal de l'Ontario - s'efforce de lancer le débat sur l'espace conflictuel, non seulement entre les époques postmoderne et postcoloniale (donc entre le modemisme et l'empire), mais aussi entre les intentions de la conservatice ou de la personne responsable de la conception et l'exposition proprement dite, dans un établissement particulier, entre l'interprétation personnelle et la réaction de la collectivité, entre la représentation en tant que critique et la représentation en tant qu'appropriation ou sanction et, finalement, entre la politique discursive de l'ironie et ce que Cornel West appelle la politique culturelle de la différence.
Abstract

It is now a truism of cultural theory that, while the terms postmodern and postcolonial obviously share more than their prefatory posts, the broad cultural enterprises which they have come to designate are by no means conflatable. This detailed critical examination of one controversial case study - the Royal Ontario Museum's 1989-90 Into the Heart of Africa exhibit - and of its aftermath attempts to open up to debate the conflictual space not only between the postmodern and the postcolonial (and therefore between modernity and empire), but also the space between curatorial/designer intention and actual realization in a particular institution, between individual interpretation and community response, between representation as critique and representation as either appropriation or endorsement, and - in the end - between the discursive politics of irony and what Cornel West calls the "cultural politics of difference."
In the contested cultural turf of today, not only are we not "past the last post"1 but the posts seem to want to proliferate. Over the last decade, the postmodern has become the polemical terrain of fierce debate as well as glib generalization; the postcolonial may well face the same fate - but the stakes may be even higher. Debates about historiography and reflexivity, and their role in the politics of cultural representation, can likely never be innocent ones; nor can they be uncontroversial in either the postmodern or postcolonial arenas. These are shared issues, even if the articulation, interpretation, and deployment of them differ considerably.
What most theorists (however they define the posts) seem to agree upon is that the reason for these mutual concerns is their common oppositional grounding in - or, rather, against what has been generalized and usually demonized into this thing called 'modernity'.

Put in the admittedly reductive (but perhaps heuristically useful) terms of 'cultural shorthand': in most accounts these days, the movement from Renaissance humanism to the beginning of the "modern project," to use Jürgen Habermas's term, starts with the Cartesian and Enlightenment shift from scholasticism to what Stephen Toulmin describes as "a higher,

Material History Review 41 (Spring 1995) / Revue d'histoire de la culture matérielle 41 (printemps 1995) 
stratospheric plane, in which nature and ethics conform to abstract, timeless, general, and universal theories."2 On this plane - or so the simplified version of the story goes - connections between knowledge and objects of knowledge (nature, the self, history, society) are said to be objectively determined, providing a foundation which permits a systematization that works toward what is seen as an inherently progressive grasp of 'truth'. Knowledge thus accrued is said to be not only culture-neutral, but valuefree. But, doubt and worries about contingency are just as much a part of the modern heritage and, of course, the debates over the politics of the ordering, legitimizing, system-building power of reason and method are themselves also part of the very history of modernity; they are also ongoing, however, with Habermas ${ }^{3}$ arguing that the "project of modernity" has not yet been completed, that its moral imperative to free humanity from injustice and to extend equality to the oppressed through rational communal grounds of consensus has not yet been achieved. Yet, what Habermas sees as liberating consensus, others have seen as inhibiting conformism, as an "obsessively legislating, defining, structuring, segregating, classifying, recording and universalizing state [which] reflected the splendour of universal and absolute standards of truth." 4

Those of us who are academics work within one of the major cultural institutions of modernity and, whatever our individual evaluation of the modern project and, whatever our personal position (consensual support or oppositional resistance), we participate in what has been called the "exercise of social control through the meting out of learning, mediated and identified with the achievement of worth." 5 But these words were, in fact, written to describe the ideological and historical assumptions of curators of ethnographic museums, not university teachers. Both the museum and the academy in Europe and North America have traditionally shared an institutionalized faith in reason and method, not to mention an often unavoidable intersection with governmental agencies; together these have contributed to the "authority effect." they each create. ${ }^{6}$ Not surprisingly, both institutions have come under considerable scrutiny from postmodern theory, intent on deconstructing that effect and its ideological consequences. Both could be said to work toward the acquisition of knowledge ${ }^{7}$ through collecting, ordering, preserving, and displaying - in their different ways - the 'objects' of human civilization in all its varieties. If it is the ideology of these processes of constructing meaning and significance that has provoked the postmodern critique, it is the nature of those very 'objects' that has initially brought the postcolonial into the academic debates - in literary criticism and anthropology especially - and, increasingly, into the discourse of museums, especially ethnographic ones. It is the latter that will be the focus here.

Over the last few decades, museums have begun to see themselves as cultural 'texts' and have become increasingly reflexive about their premises, identity, and mission. ${ }^{8}$ Among the questions asked anew are: Do objects speak for themselves? If so, how? What objects have been collected, and why? What constitutes the socalled authenticity of an object $?^{9}$ The history and economics of collecting have received much attention lately from many quarters, as have the current legal, ethical and financial constraints on acquisition, custody and disposal of 'cultural property'. ${ }^{10}$ But the history of most European and North American ethnographic museum collections is one that cannot easily be separated from the specific history of imperialism. ${ }^{11}$ Not only were the objects collected often the spoils of colonial conquest (seen at the time as 'discovery' and 'exploration'), but their acquisition and retention have been legitimated by the institutionalization of an ideal (and an ideology) of apolitical, detached objectivity and a positivist commitment to science. ${ }^{12}$

This connection between historical imperialism and what some now see as intellectual imperialism ${ }^{13}$ might best be understood within the context of the common denominator of what I too have here been calling - in admittedly reductive shorthand terms - modernity. In very general theoretical terms, it could be said that assumptions of neutrality and objectivity and of the value of rationality, empiricism, and technology are 'modern' assumptions that form the practical foundations of the post-Enlightenment public museum, even today. If museums are still structured on "rigid taxonomies and classification, whereby it was believed that artefacts could be laid out in a consistent, unitary and linear way," 14 it is because they are still in some ways the physical embodiments of modernity's desire to make order and therefore meaning. What some see as the universalization inherent in the Enlightenment project ${ }^{15}$ works to smooth over gaps and unite fragments into a systematized cultural totality. One of the manifestations of this process is the display of diverse, culturally specific objects in highly aestheticized, ${ }^{16}$ (architecturally) late modernist galleries that effectively wipe out particularity of context 
or history. Of course, the very act of technically preserving objects from the ravages of time and decay (not to mention that of 'restoring' them to their 'original' state) could be seen as universalizing in its denial of change over time. This stewardship model of the museum as the guardian of the human heritage entails going beyond this conservation function to include a scholarly and educational mandate, both for experts and for the general public.

In the last twenty years or so, however, experts working in the field of ethnography have articulated in a museum context the postmodern view of culture as text, reminding us that such 'texts' are interpreted and contextualized by ethnographers themselves. To borrow from the title of one of Clifford Geertz's influential books, the aim of "interpretive anthropology" is "local knowledge." ${ }^{17}$ What James Clifford has called a "conceptual shift, 'tectonic' in its implications"18 in ethnography is, in fact, a response to modernity by the postmodern, with major postcolonial implications. Gone are the days, writes Clifford, when anthropology (conceived of as apolitical and neutral) could speak "with automatic authority for others defined as unable to speak for themselves." 19 The acknowledgement - at last - of the "unequal power encounter" 20 that marks both the discipline of anthropology and, in a different way, colonialism itself has brought the politics of representation to the fore. The universalizing urge of modernity then begins to give way to the postmodern cultural politics of difference, described by Cornel West as the drive

to trash the monolithic and homogeneous in the name of diversity, multiplicity and heterogeneity; to reject the abstract, general and universal in light of the concrete, specific and particular; and to historicize, contextualize and pluralize by highlighting the contingent, provisional, variable, tentative, shifting and changing. ${ }^{21}$

What has been referred to (if not generally accepted) as the 'new museology' works in this contentious territory, asking what the different purpose of the museum would be if it gave up its modern claims of neutrality and objectivity and what the role of the spectator could be in the now acknowledged act of the interpretation of objects, objects which do not independently transmit meaning but, rather, are open to many possible constructions of meaning depending on things like the design of the display, the context in the institution, the visual semiotics engaged, the historical background presented. ${ }^{22}$ How- ever, not only objects change meaning over time; so too does the museum itself as institution, for it too is a constantly evolving social artifact ${ }^{23}$ that exists in a constantly changing social world. The postmodern discourse of museums now includes concepts of community access and involvement, of two-way interactive communication models, and of empowerment through knowledge. ${ }^{24}$ There is talk of a desire to find ways to engage with living cultures rather than only with objects of the past, of a desire not only to inform but to provoke thought.

This is the general context for the particular focus of this article: one museum exhibition that certainly did engage with its immediate community and that definitely provoked thought, not to say controversy; it was an exhibition that put into play those familiar postmodern discursive strategies of irony and reflexivity in order to attempt to deconstruct the ideology of Empire that determined its particular collection of African objects. It thus ran counter to the more customary (unavoidable, but usually discreet) indirect mention of imperial provenience that could be read as an attempt to "close its history at the end of the colonial era itself." 25 From 16 November 1989 to 6 August 1990, the Royal Ontario Museum in Toronto, Canada, presented an exhibition entitled Into the Heart of Africa. This was the first complete (and thus long-awaited) showing of the small African collection of the museum, but what began with good intentions ended with picketing by members of the African Canadian community, court injunctions against them by the museum, encounters between demonstrators and police that led to criminal charges being laid, and the decision of Jeanne Cannizzo, the curator ${ }^{26}$ (a white anthropologist and expert on African art), to leave her part-time university teaching position for a complex set of reasons, including continuing accusations of racism. Yet this was an exhibition that attempted to be the opposite of the kind of thing one might find in an institution like the Royal Museum of Central Africa near Brussels, where a statue of Leopold II dominates a room "celebrating the triumphs of colonialism with the guns and flags of expeditions and the chests carried by native bearers, the plumed hats of the conquerors, models of their railway lines and the honoured names of those who laid down their lives controlling the natives."27 Those guns and flags and plumed hats were present in the (similarly named) Royal Ontario Museum too, but the stated aim of this exhibition was to expose the imperial ideology of the people - Canadian soldiers and 
missionaries - who had borne them and who had brought back to Canada many African objects which, over time, found their way into the museum.

The intention - at least, as articulated after the fact by museum authorities - was to offer a (postcolonial) "critical examination of the Canadian missionary and military experience in turn-of-century Africa;"28 the mode of presentation was what museologists would have recognized as postmodern in its foregrounding of how objects changed meaning over time and in different contexts. But the self-evident difficulty of effectively deconstructing a museum from the inside became acute when that institution was viewed by at least some members of the African Canadian community as part of European modernity's "attempt to measure, categorize and hierarchize the world with the white male on top. And all at the expense of the African, Asian and aboriginal peoples." 29 In a city like Toronto (and in a country like Canada), ${ }^{30}$ where the multicultural and multiracial mix is perhaps as great as anywhere in the world today, what cannot be ignored is the inevitable change in what the social meaning of a museum might entail. If, from the perspective of postmodernity, a museum is a means by which a society represents its relationship to its own history and to that of other cultures, ${ }^{31}$ then changes in that society should also be reflected in the institution, whose meaning - like that of the objects within it - is arguably a constructed and negotiated one.

Canadian society has changed radically since World War II: outside Quebec, its once British majority has sometimes found itself, in large urban centres in particular, in a minority position. Such is the case in Toronto, where the influx of immigrants from southern Europe, South Asia, Africa, the West Indies, and the Middle and Far East has made the city multiracial as well as multiethnic. Since many of the new arrivals came from other Commonwealth countries, there was an inevitable new awareness of both similarity and difference in the experience of Empire. If colonialism can be defined as a broad form of structural domination, ${ }^{32}$ there are going to be many varieties of it: "to be one of the colonized is potentially to be a great many different, but inferior, things, in many different places, at many different times." 33 Many working in postcolonial studies today stress the distinctions even within communities, based on gender, class, race. ${ }^{34}$ Others have pointed to what are, in this particular case, important differences between kinds of colonies - for example, between so-called settler colonies ${ }^{35}$ like Canada and invaded ones like the many in Africa. ${ }^{36}$ Both may indeed partake of that "specifically anticolonial counter-discursive energy" that some see as postcolonial, ${ }^{37}$ but there are important differences ${ }^{38}$ that are crucial to the responses to Into the Heart of Africa, differences that obviously involve the "unbridgeable [racial] chasm"39 between white and non-white colonies, as well as the related cultural and historical chasms between settler and subjugated colonies. In the latter, cultural imposition took place on "the body and space" of Empire's "Others" 40 through military and bureaucratic power.

While I do not in any way want to underestimate either the multiplicity of historical (and current) responses to Britain and Empire from Canadians of other than British backgrounds or the trauma of settler colonies like Canada, which have had to deal with the psychic and cultural (as well as economic) dependency of colonization and have struggled to articulate autonomy through constitutional or cultural means, ${ }^{41}$ I cannot help thinking that the problems at the Royal Ontario Museum a few years ago stemmed in part, at least, from the difference between Canada's relation to Empire (as a settler colony) ${ }^{42}$ and that of Africa's nations, invaded by European (and in this case, Canadian) powers and subjugated to them by military might or missionary evangelism. The term "postcolonial" is simply going to mean different things because the experience of colonization has meant different things. While Canada may well want to position itself oppositionally as postcolonial today, in order to make what Kwame Anthony Appiah calls a "space-clearing gesture" ${ }^{43}$ for its New World selfdefinition, this particular exhibition — with its focus on the Canadian role in the colonizing of Africa - forced an awareness of English Canada's official historical position within Empire. Not everyone liked this new self-image: to use Albert Memmi's strong terms, Canada was suddenly "disfigured into an oppressor, a partial,...treacherous being, worrying only about...privileges and their defense." ${ }^{44}$ Canadians (or more specifically white English Canadians) were shown that their own history was not separable from the colonizer's struggle to reconcile "the notions of political freedom cherished by [the] home country with the actual political suppression and disfranchisement of the colonized people." ${ }^{25}$ Black Canadians, as we shall see, were positioned rather differently. But, as a nation, Canada was represented 
as having an uncomfortable dual historical identity as both colony and colonizing force.

Such is the troubled and complex postcolonial setting for this exhibition; but there is a parallel and equally contested context that involves the postmodern as well: its ironic and allusive nature was identified early on as part of the problem. Irony and reflexivity have become almost hallmarks of the postmodern (though, of course, in no way restricted to it). The postcolonial and the feminist enterprises, among others, have also often turned to irony as what Richard Terdiman calls a "counterdiscourse," 46 as the rhetorical figure of the dialogic whose "function is to project an alternative through which any element of the here-andnow may be shown as contingent, and thereby subject the whole configuration of power within which it took its adversative meaning to the erosive, dialectical power of alterity." As the "linguistic repository of difference," irony, when seen as an oppositional strategy, ${ }^{47}$ can work to problematize authority, including the modern assumptions about museums' structures and forms of historical authority.

A related postmodern motif, one that recurs in much of the writing on the 'new museology', is a call to institutions to make themselves and their publics aware of the history of their collections and of the values embodied therein. ${ }^{48}$ It is argued that reflexivity about historical role and context can have the potential to raise important political, epistemological and aesthetic issues. ${ }^{49}$ The 'metatext' would make visible to the public the ways to read and make sense of a display as text, as well as offer the history of the choices leading to it. ${ }^{50}$ It seems to be assumed that such internal self-awareness would lead to a liberation from the constraints of modernity's concepts of apolitical ${ }^{51}$ scientificity and authority, and thus free museums to take on what previously might have been considered risky or controversial subjects, because the public would now be made more aware and less complacent about what they expect to find in a museum. If combined with "wider historical experiences such as explorations of colonial relations,"52 it has been argued, new questions might be provoked. Into the Heart of Africa certainly provoked many questions - about colonialism and the relationship between the politics of culture and the politics of meaning and representation ${ }^{53}$ but it was reflexivity itself, like irony, that came under fire. ${ }^{54}$

Actually, almost everything about this exhibition came under fire, from its focus to its subject matter — indeed, even its title: Depending on how you interpret Conrad's Heart of Darkness, the echoing of the novel's title in Into the Heart of Africa is going to suggest either an imperialist perspective or a critique thereof. ${ }^{55}$ From the start, then, this ideologically freighted doubleness encodes in microcosm the terms of the ensuing conflict over the show's interpretation and evaluation of imperialism. ${ }^{56}$ The museum's later stated intent was "to explore attitudes of the past but not, for a moment, to suggest that the ROM endorsed the biases of those times." 57 That there was considerable confusion about this intention was evident within a few months of the opening, however.

Prior to this occasion, the museum's small and fragmentary collection of 375 objects from Central and West Africa had remained in its basement for almost a century, available as a whole only to researchers, though isolated parts of it were displayed in some of the ethnography galleries. It was fragmentary because it lacked, in the curator's words, "chronological depth, geographical concentration or ethnographic focus" ${ }^{58}$ and the reasons for this lay in the history of its acquisition. It had come into being largely through bequests from the families of Canadian missionaries and soldiers in the British African colonies at the end of the last century and the beginning of this one. This is where the problems with the collection's unrepresentative nature also began: military men often collected weapons and missionaries tended to bring home things like hair pins or combs or musical instruments that they could display when fund-raising. In other words, this was not a full collection of a range of African objects; there could be little pretense that it would represent the cultural diversity, social complexity, or artistic achievement of the multiple peoples of Central Africa. ${ }^{59}$

For this reason, the decision was made to foreground in the exhibition both the material limitations of the collection and the history and politics of its coming into being in this one, specifically Canadian, cultural institution. The openly articulated intent was one familiar to postmodern anthropological theory: to focus on the imperial ideology of those who collected the objects (for which rich archival materials did exist), on how those objects came to enter this museum, and thus on the more general cultural assumptions of museums and of the disciplines of museology, anthropology, and history. In short, the focus was not to be on Africa itself. In addition, given this meta-museological 
1

Crown \& Empire" zllation from Into the tt of Africa exhibit, 3-90, Royal Ontario eum, Toronto, ada. (Courtesy Royal irio Museum)

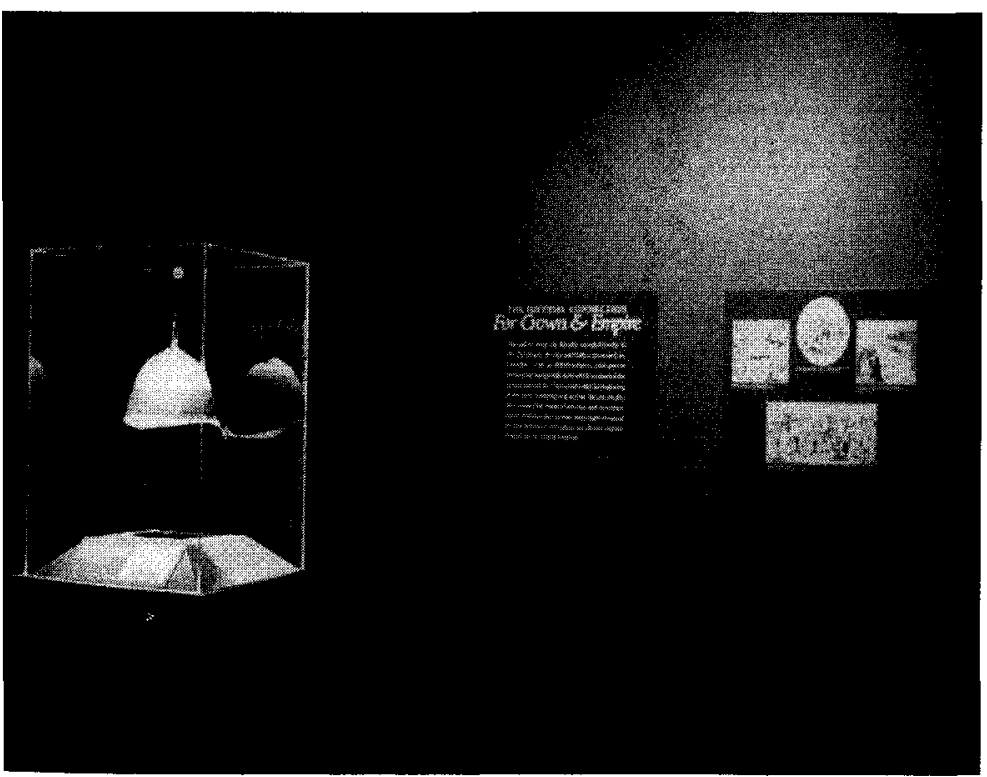

African religious, social and economic life is celebrated through objects brought back by Canadian missionaries and military men over 100 years ago." But this description seriously misrepresented not so much the material as the focalization of the exhibition: the focus was never intended to be entirely on Africa itself, but on the material manifestations of the ideology of Empire in Africa.

Why, then, would the brochure mislead? One reason might be that this was the second one printed. At the cost of over $\$ 20000$, the first was scrapped when consultations with members of the African Canadian community led to complaints against what was called its "tired, stereotypical language"63 about Africa, language that "subtly recalled the glory of the Imperial Age." But the fact remained that the second brochure, however closer it might have been to representing what the community would have liked the exhibit to be, actually proved seriously misleading with respect to the reality. In this way, the initial decision as to the focalization of the show became a primary point of contention. The first printed message at the entry to the exhibition openly stated that Canadians (implicitly, white British Canadians) were to be the focus, that their "experience of Africa, as seen in this exhibition, was very different from the way Africans perceived themselves, their own cultures, and these events." The objects presented, it continued, "remind us of a little-remembered era of Canada's past." The first-person plural pronoun here was problematic, not only in its implicit exclusions (perhaps some African Canadians did indeed remember that past ${ }^{64}$ ), but also because not all of those white European Canadians so "hailed" by the pronoun wanted to be reminded of such a past. The museum's news release about the exhibition mentioned that in the Military Hall section, "the visitor will be able to understand Zulu warfare from the other side of the battlefield" (my emphasis), perhaps implying that the visitor, in this case, was expected not to be Zulu and perhaps even to be white as well as British or Canadian.

Certainly, the initial, almost empty (and, for me, imperial) blue rooms labeled "For Crown and Empire" set up the historical relation of Canada to the British Empire in Africa in the last century (Fig. 1). A few objects (both African and imperial) were presented here in a traditional museum fashion, isolated in their beauty in glass cases, abstracted from their context and function. Although everyone 
connected to the museum ${ }^{65}$ insisted that the irony and reflexivity of the show were meant to signal the detachment of the institution from the imperial perspective being presented, the textual markers of that intention were less than clear and self-evident. In these first rooms, for instance, there was no semiotic signal to separate the African from the imperial, despite the later claims that the intent was to show the beauty of the African objects as a way of refuting "the nineteenth century $[s i c]$ Canadian supposition of barbarism." 66 But was one also to admire the shining, ribboned and plumed British-Canadian officer's helmet similarly placed in a locked glass case? The curator may have intended here a kind of reflexive "ethno- graphizing" effect, ${ }^{67}$ but the context of the museum as a whole (where such glass cases are un-ironized commonplaces) worked against the likelihood of such a result. The beauty of the objects and the emptiness of the room made this feel for some like a kind of holy place where Empire was being revered and admired. 68

What jolted the viewer out of this mood, however, was the fact that, visible from the entrance, was an enormous, wall-sized enlargement of an image of a mounted British soldier thrusting his sword into the breast of an African warrior (Fig. 2). This was labelled (none too readably) "Lord Beresford's Encounter with a Zulu." The text posted nearby identified this

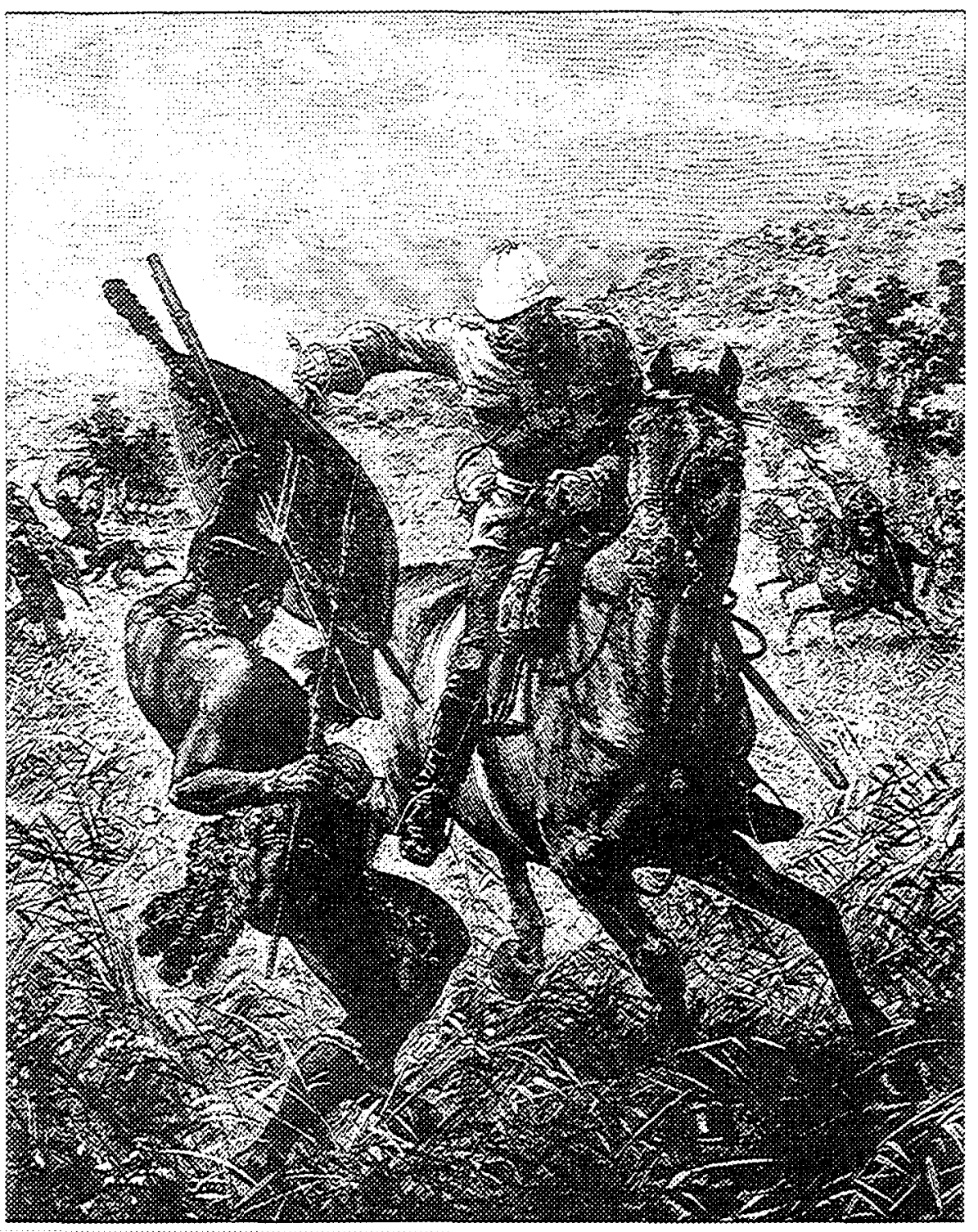

Fig. 2

Lord Beresford's

Encounter with a Zulu.

Cover of the Illustrated London News Vol. LXXV, no. 2099. Saturday, 6 September 1879. (Courtesy Royal Ontario Museum) 
as the cover of the Illustrated London News of 1879. As you can imagine, the impact of this kind of image is going to be different on a small catalogue page, where it is also reproduced, than it is on a large wall. As many commentators subsequently noted, the violence of this representation worked not to produce a response against jingoistic Victorian imperialism (as was intended ${ }^{69}$ ), but to turn the tables against the exhibition itself for perpetuating precisely such representations. In today's culture, where visual images may indeed make more of an impression than printed text, and in an institution visited by schoolchildren of all ages and races who just might not stop to read the contextualizing accompanying texts, the placing and size of this image were, at the very least, signs of semiotic inattention or inexperience. While the relationship of text to image is a general problem for all museum exhibits, ${ }^{70}$ here it proved critical because many African Canadian visitors could not bring themselves to move beyond this violent representation of their race's history.

After the contentious "Military Hall" section over which this image loomed, a relatively small area called "The Life History of Objects" constituted the only explicitly meta-museological part of the exhibition itself. The reconstituted front hallway of a Canadian house revealed the movement of African objects (such as spears and shields) from being spoils of war to becoming pure (if exotic) decoration - before being donated to the museum. This section indirectly raised questions about appropriation and exploitation, but did not offer any answers or even any extended commentary. ${ }^{71}$ This was more postmodern deconstruction than postcolonial exposé, in other words, and the ambiguities made possible by its rhetorical strategy of indirection even allowed one visitor to suggest that, for her, this home setting was a kind of humanizing of the experience of imperialism. ${ }^{72}$

The next section took the form of a large, bright, white, cross-shaped room, labelled "Civilization, Commerce, and Christianity," and in it were presented the artifacts collected by missionaries (who thought they were bearing "light" to the "dark continent," as texts explained). There were also photographs of these evangelical Christians with their African converts. The last and largest area of the exhibition was entered by way of a reconstruction of an Ovimbundu village compound from Angola, wherein some of the objects seen in cabinets elsewhere were inserted into a simulated context of use. The final large room, containing drums, masks, textiles, headdresses, weapons, and musical instruments (including earphones for listening to African music), was introduced by a reflexive message attesting to the "impossibility actually to reconstruct another cultural reality in a museum. The artifacts you see here are displayed according to their 'function' or 'form' in a way that would be quite familiar to late nineteenth-century museum-goers, but not the people who made them. The things are theirs, the arrangement is not." Such a sign was intended to mark the change in interpretive emphasis at this point in the exhibition, as the theme changed from the history of the collection to the objects themselves, which were said to "speak of the varied economies, political or cosmological complexities, and artistry of their African creators." ${ }^{33}$ Yet the problem with calling attention to the fictional or artificial arrangement of the objects in this particular space became evident when you considered it in the context of the rest of this museum, where such traditional arrangements are still the norm for even the twentieth-century museum-goer. Given that, in Western culture, priority is usually signalled by position, there was yet another potential conflict between the intention - to show that 'African cultural life and historical experience were not being reduced to a codicil of imperial history ${ }^{74}$ - and the fact that this section did come after the one that focussed on imperial acquisition.

The corridor leading out of the exhibition housed a scattered and miscellaneous collection of small photographs of Africans today, evidently in an attempt to give a sense that, although the collection may be historical, the realities of urbanization and industrialization have brought many changes to African society. Just outside the doorway was an African museum-store 'boutique' which eased the visitor back into Canadian consumer society, thereby coming full circle, since the initial (conventional) sign thanking corporate sponsors set up (for me, as for others) an ironic frame: if anyone should have been acknowledged as being those without whom this show would not have been possible, it was the Africans who made the objects displayed.

Even my brief description (itself hardly innocent of bias) might offer some clues as to why Into the Heart of Africa managed to engage so much strong emotion in so many very different people. As one critic remarked: 
What was most amazing was that the exhibition offended audiences from all parts of the political spectrum: missionaries whose colleagues were depicted in the exhibition, the descendents of colonial officers whose collections were shown..., and most strongly, Africans and people of African descent who saw the exhibition as racist and insulting. The exhibition was also offensive to some within another, somewhat less vocal group, that is, historians of Africa, art historians, and anthropologists working in universities and museums. $^{75}$

One might add to that list even liberal, white Canadians who thought of themselves as multiculturally tolerant and even postcolonially oppositional. But what specifically enraged and offended people? The anger of many was provoked as much by the visual representation of verbal texts as by any actual objects or pictures. ${ }^{76}$ From the start, explanatory signs presented certain words framed in quotation marks. An interpretive conflict was set up at once: were these citations (and thus historically authenticated and validated) or were they to be read ironically? Words like "the unknown continent," "barbarous," and "primitive" were placed in these quotation marks, but the problem was that so too were metaphors, titles, and some object descriptions. In other words, the proliferation of quotation marks made the visitor wonder whether those placed around words like "Dark Continent" and "primitive" could or should be read as intended both to signal ironic distance ${ }^{77}$ and also to act as accurate citations - in other words, to represent the colonial perspective that the postcolonial exhibition wanted to show it did not share. ${ }^{78}$ In the museum's own initial news release, there was arguably some awareness that people might not know exactly how to interpret such quotation marks, for it added "what was then called by some the "unknown continent"' (emphasis mine). The curator, in a later article, likewise wrote of "the alleged barbarity of 'savage customs "." ${ }^{79}$ Of course, inverted commas or quotation marks are a commonplace rhetorical technique (used to disclaim and to distance, while still echoing) in 'new museological' theorizing (and even, obviously, in this article): for instance, in a piece entitled "The Future of the Other: Changing Cultures on Display in Ethnographic Museums," Brian Durrans writes of "a world where the 'primitive' other has long been the victim of imperial domination." 80
But when the context is not academic or museological, the interpretation of these ironizing quotation marks may differ. For some visitors to Into the Heart of Africa, they were simply disapproving disclaimers; ${ }^{81}$ for others they were a form of devious "sugarcoating." One viewer, whose great-uncle was featured as one of the Canadian military, found that they created too subtle an irony, one "lost on those who can't (or don't) read the explanatory texts." She added: "it is also a pretty limp way to examine a subject as grave as racially motivated genocide." ${ }^{83}$ The Curriculum Adviser on Race Relations and Multiculturalism for the Toronto Board of Education went even further, stating: "In dealing with issues as sensitive as cultural imperialism and racism, the use of irony is a highly inappropriate luxury." ${ }^{84}$ And yet...feminist, not to mention postcolonial, theorists have argued that irony is one of the most effective ways of dealing with precisely such difficult issues - at least when used oppositionally from within. But there was the rub: this irony was perceived as coming from a colonial source, even if a self-deconstructing one, and even if the irony was largely at the expense of imperialists not Africans.

One instance of ironic citational signaling was mentioned in almost every public response to this exhibition: ${ }^{85}$ it was the relation between a missionary photograph of a white woman watching a number of black women doing washing and its caption - "Taken in Nigeria about 1910, this photograph shows missionary Mrs. Thomas Titcombe giving African women 'a lesson in how to wash clothes'. African labour was the mainstay of mission economies." To the Coalition's interpretation - "Did Africans not know how to wash before the arrival of Europeans?" ${ }^{86}$ — one white Canadian reviewer replied: "An observant reader will note that the words 'a lesson in how to wash clothes' are in quotation marks. The description is offered as evidence, not of the actual activity, but of Mrs. Titcombe's intentions and sense of superiority." ${ }^{87}$ But I hasten to add the obvious: the comprehension of irony has never been quite that simple. The curator might have intended the labels in this "Civilization, Commerce, and Christianity" section to show "the sense of cultural superiority" inherent in the missionary goals, ${ }^{88}$ but if, as Homi Bhabha has argued, ${ }^{89}$ colonial discourse contains both colonizer and colonized, caught in a problematics of indeterminacy and ambivalence, then does this sort of irony re-enact (even as it critiques) "an ambivalent mode of knowledge 
and power?"90 Does this particular irony embody manichean dualisms or subvert them? Or does it depend on who is doing the interpreting? And, on a more pragmatic level, what about visitor expectations about the conventions of museum labelling? In an institution where the norm is that visual messages and verbal texts convey the same meaning, the risks taken through ironic disjunction here are great. And, of course, what if people do not read the labels at all? ${ }^{91}$

Another related and equally problematic part of the exhibition was a small white room where visitors could sit to watch a slide show and listen to a male voice give a 7 -minute re-creation (from missionary archives) of a magic-lantern illustrated lecture called "In Livingstone's Footsteps." This was presented as what a missionary might have said, in 1919, to his Ontario protestant congregation when fund-raising for his African mission. The fictional context was asserted orally at the outset and again at the end. In addition, outside the room was a notice that read:

The sense of cultural superiority and paternalism that you will hear in this fictional narrative was characteristic of the missionary worldview at the time. So was the genuine spirit of adventure and the sincere belief that missionaries were bringing "light" to the "dark continent."

But what if you did not read the sign? What if you missed the beginning or end of the long 7-minute tape? Well, you certainly heard the "cultural superiority and paternalism," but without the ironizing, contextualizing frame. And, even more unfortunately, the paternalistic voice could be heard as you walked through this part of the exhibition, aurally framing your viewing, driving one exasperated visitor to exclaim that the "unctuous voice delivering highly derogatory commentary could have been that of the ROM's director on his intercom for all I knew." "92

However didactic or heavy-handed ${ }^{93}$ some people might have found the ironies in the exhibition, it was not by any means a matter of their being paradoxically too subtle for the protesters; nor do I think the negative response was simply the result of willful misreading. ${ }^{94}$ One commentator felt that the ROM acknowledged the failure of the ironies but implied that it was the fault of an unsophisticated audience. ${ }^{95}$ The Coalition for the Truth about Africa, however, argued that the subtleties of irony could not compete with the power of images of subjugation. ${ }^{96}$ (Nevertheless, several of the demonstrators themselves used irony in their protests to claim a position - but this too was irony that was interpreted as differently from its intent as the exhibit's had been.) For still others, the show's ironies were both scholarly and subtle and therefore elitist. ${ }^{97}$ Irony has always been risky, but here the stakes were particularly high, especially for the institution: this was its first highlighted exhibit of this African material; the city was facing racial tensions over police shootings of black youths. Even if irony were appropriate here, the desirability of framing it less ambiguously became increasingly evident.

Framing helps to delimit response, of course; nevertheless, response also depends on the particular audience doing the responding. The very indirection of the ironies here might well presuppose an audience (liberal, white, European Canadian) that can - or is willing to read between the lines: that is, an audience that positions itself as postcolonial and multicultural, and not as colonial and racist. Is there not a danger, however, that even this audience might be lulled into thinking that the irony has done its critical work for it, and that it need only bother to question those words set apart in quotation marks? ${ }^{98}$ After all, there are no ironic quotation marks around the description of David Livingstone as a hero - though many Africans (were their point of view offered) might insist upon their appropriateness. ${ }^{99}$ Do the existing ironies implicitly rely too much on an audience that can be affectively and politically detached from the pain represented in the exhibition's visual images? ${ }^{100}$

The issues of the so-called 'misreading' of irony and of the appropriateness of its very use on this occasion are issues which engage in complex ways the exclusionary potential of irony - and therefore of the anger it can cause. But the affective charge of anger can also extend to the target of the ironies, and, indeed, many did protest the stereotyped portrayal of the Canadian missionaries in the exhibit, arguing the case for their more complex and frequently oppositional relationship with colonial authorities. ${ }^{101}$ But this was a muted protest compared to the Coalition's, which argued that African Canadian children came away from Into the Heart of Africa with a negative impression of black history, with the idea that Africans did not know how to wash their clothes or comb their hair before the whites arrived. ${ }^{102}$ No one, to my knowledge, however, argued that white, British Canadian children came away embarrassed or traumatized to learn that their families had been 
guilty of everything from paternalism and exploitation to extermination. Yet columnists did note that, if the exhibition was hard on any group, "it was the white missionaries and soldiers; their prejudices and ignorance are documented in some detail;" 103 one black reviewer even suggested that the exhibit promoted racism against whites who were made to look ignorant and dangerous. ${ }^{104}$ As Robert Fulford summed it up: "old-time Christian missionaries are now almost beyond the range of human sympathy." 105

Irony has always been a trope that depends on context and on the identity and position of both the ironist and the audience. A feminist literary critic, writing in a book about women and comedy, can begin an article entitled "Jane Austen: Irony and Authority" with: "It is a truth universally acknowledged, right now, that language is involved in giving and taking both power and pleasure,"106 and expect that her readers (themselves self-selected and having at least read her title) will understand both the allusion to the opening of Pride and Prejudice and the irony. If it is true that jokes do not travel well because of the need for shared knowledge, ${ }^{107}$ then this is even more the case with irony. I would argue that discursive communities do not come into being as the result of people sharing irony together; ${ }^{108}$ they are what make irony possible in the first place. The many discursive communities to which we each, differently, belong can be based on things like language, race, gender, class, and nationality - but might also encompass all the other micropolitical complexities that constitute (or are made to constitute) our identities. The infinite variations and combinations possible are what make irony both relatively rare and in need of markers or signals. It is almost a miracle that irony is ever understood as an ironist might intend it to be: all ironies, in fact, might therefore be unstable ironies. ${ }^{109}$

Those deployed in Into the Heart of Africa were received very differently by different discursive communities, as was the show as a whole. To a black lawyer and activist, the effect of seeing Africa through the eyes of those who colonized and killed was chilling; ${ }^{110}$ to a selfdescribed "white Canadian liberal," the exhibit was "a recognizable piece of British-Canadian history" - not a show about Africa and not about the present. ${ }^{111}$ Research on the complexity of how people experience an exhibit suggests that responses might be idiosyncratic, but that the general public (whatever that might be) is very likely going to respond differently from what professional critics and curators might expect. ${ }^{112}$ One of the reasons is that visitors usually belong to different discursive communities: they bring "a multiplicity of different attitudes and expectations and experiences to the reading of an artefact, so that their comprehension of it is individualized." 113 So too is their affective response to it. Where white Canadians might find the exhibit a self-searching, ironic examination ${ }^{114}$ of historical intolerance, black Canadians saw the "painful detritus of savage exploitation and attempted genocide" and a perpetuation of racist attitudes of white superiority. ${ }^{115}$ Even the use of irony was read by some as belonging to a white culture's model of discourse, ${ }^{116}$ and its use (and alleged incomprehension) seen as a replication of the missionaries' attitudes. ${ }^{117}$ This kind of objection goes beyond the question of whether, in this particular case, irony was used well to question the very appropriateness of the trope itself.

As a white Canadian visitor of European (though Italian, not British) background, I certainly felt that I was being "hailed" by the references to "Canadians" in the show, in the press releases, and in the brochure, where the late nineteenth century in Africa was described as a "turbulent but little-known period in history." The point was made well by the critic who pointed out: "For whom... was this period merely turbulent, and to whom is the period so little-known?"118 The answer is: white Canadians...perhaps. The answer is not: the black protester who said, "All my life I've been looking for my roots, I come here looking for them - and you've shown me nothing." 119

The exhibition's configuration of the imagined community called Canada, to use Benedict Anderson's description of a nation, ${ }^{120}$ was a limited one, to be sure. But race was not the only issue. If position in "social space" determines the point of view of each individual agent, ${ }^{121}$ then your perspective on Into the Heart of Africa was not going to be separable from things like class and education. If, as Pierre Bourdieu argues, economic power is mobilized through symbolic power - which comes from having and accumulating "cultural capital,"122 then the very question of who it is who regularly goes to a museum becomes a relevant issue. Surveys in North America and Europe suggest that the most frequent adult museum visitors are well educated, middle-class, ${ }^{123}$ and relatively affluent. ${ }^{124}$ They may visit as tourists, volunteers, teachers (with student groups), self-educators, or 
researchers. The question is whether, despite this relative homogeneity, you should ever assume that visitors will necessarily share the "values, the assumptions and the intellectual preoccupations that have guided not only the choice and presentation of exhibitions, but also, more fundamentally, the selection and acquisition of objects." 125 When the audience includes African Canadians, from whose ancestors' cultures came the objects displayed in Into the Heart of Africa, such a question is not a neutral one. Many commentators noted that the show seemed to be designed for and aimed at white, educated, liberal-minded people with an interest in museums and anthropology; ${ }^{126}$ to assume any broader consensus about an exhibition of African objects was, perhaps, not to take sufficiently into account the growing black population of Toronto and the different discursive communities to which they might well belong ${ }^{127}$ (and along with those, the different expectations, different assumptions, different associations with museums in general).

In an explanatory article written after the closing of the exhibition, the curator herself defined museums as social institutions which "cannot be divorced from the historical context in which they developed, and their collections occasionally reflect the violence and disruptive social forces characterizing the European colonization of Africa."128 While that violence was made more than clear in some of the visual images within the exhibition, what was missing from it was this very kind of overt statement of judgement. Into the Heart of Africa was, in other words, postmodernly deconstructive; it was not postcolonially oppositional. The indirection and obliqueness of its irony in fact worked to render the exhibition's position ambiguous. The use of irony might well have been intended as a way of subverting the ideology of colonialism from within - and thereby also avoiding openly offending the missionary and military families (and their descendents) who had loaned and donated so much to the museum. This might have been a postmodern possibility; it certainly was not seen by most visitors as a postcolonial one. The very depiction of racism (in the past) was interpreted by some as - not only Eurocentric - but racist (in the present). ${ }^{129}$ The problem of embodying that which one is trying to analyse and the difference between endorsing and examining are pragmatic issues of crucial importance in postcolonial theory today. In this exhibition, Africans tended to be represented as passive, as victims, as physically smaller and positioned lower in pictures: this was because such indeed was the view of the colonizers. But the difficulty was that it was also the only view offered in the exhibition; so too was theirs the only voice. Presumably, the assumption was that the visitors would be able to distinguish between the voice represented on the labels (some in quotation marks) and the voice of the museum. There was much evidence of a certain confusion over this, however. After all, why should visitors assume, knowing all that these colonial collectors had given to the museum, that the institution was necessarily (or even likely) going to be ironic about or critical of them? ${ }^{130}$

The ideology of collecting itself has become a major interest of postmodern museology, it is true. Theorists have studied issues such as the gendered and historically specific way in which the passion to collect, preserve and display has been articulated, the role of collections in the processes of Western identity formation, ${ }^{131}$ and the representativeness and presentation of collections. There has been a certain amount of postmodern demystification of what I began by referring to as the modern - and often unacknowledged - institutional practices that, from a postmodern perspective, might be expressed in such terms as: "The collector discovers, acquires, salvages objects. The objective world is given, not produced, and thus the historical relations of power in the work of acquisition are occulted. The making of meaning in museum classifications and display is mystified as adequate representation." "132 It was in order to contest precisely this ideological position of modernity that the catalogue of Into the Heart of Africa argued:

A museum collection may be thought of as a
cultural text, one that can be read to under-
stand the underlying cultural and ideological
assumptions that have influenced its creation,
selection, and display. Within such a collec-
tion, objects act as an expression not only of
the worldviews of those who chose to make and
use them, but also of those who chose to col-
lect and exhibit them. ${ }^{133}$

The catalogue directly addressed issues such as the museum as cultural "charnel house" (p. 80), full of the remains of dead civilizations; the decontextualized museum display as "cultural vandalism" (p. 84) and aestheticism (p. 88); and the danger of partial collections promoting stereotypes (p. 86). This was a postmodern document in that it worked to show 
how the "relations of power whereby one portion of humanity can select, value, and collect the pure products of others need to be criticized and transformed."134

As I understand the term, to be postcolonial, however, the exhibition would have had to present and then make a judgment about the effects of colonization, not simply outline its intentions. Emblematic of the rhetorical strategy of the show as a whole was the curator's later description of the Europeanization of African social structures, dress and habitation: "These changes would transform the women from producers of baskets, garden foods and pottery into consumers of soaps, spoons, forks, while tying them tightly to the developing mission economy." 135 Whether you read this as ironic would depend upon your valuing of soaps, spoons, and forks. Likewise, the subsequent statement that such practices "weakened alliances between lineages, discouraged the intergenerational and polygynous family, emphasized the loyalty of the couple to each other at the expense of kindred, and created a different concept of privacy" would not necessarily be read as critical at all within certain discursive communities. Indeed, it would not be hard to read it as a (modern) authoritativesounding assertion of anthropological or historical 'fact'. A black writer responded to this strategy by saying that the exhibit "used the propaganda of the period without proper explanation or preamble. [The curator] did not want to manipulate the material, but she ended up implanting racist images because the critique of 'intellectual arrogance' did not come through. People missed it." 136 Sometimes, they might have missed it because it was not adequately marked, because it remained ambiguous in its silence about the effect of such arrogance upon the Africans. Because the only perspective offered was that of the colonizers, you were indeed told that the missionary involved in the social transformations just described never understood the effect his changes of custom had on kinship alliances, for example, but you were not told what those effects actually were. ${ }^{137}$ As one anthropologist reviewing the exhibit remarked, it went to great lengths to remind you of the process by which objects arrived in the museum as the result of Canadians' participation in an act of conquest, but:

What about this conquest? Was it brutal, violent and shameful? Or should we, when passing the soldiers' suits and the prizes the soldiers stole from sovereign African kingdoms, swell with pride and admiration for men who braved great distances and terrible dangers to subdue fierce natives? The exhibition is strangely silent here, as if there were no moral or political issues involved. ${ }^{138}$

For a museum to choose not to take an unequivocal stand might be interpreted as a postmodern refusal of any single, modern, 'master narrative' of truth; ${ }^{139}$ but from a postcolonial perspective - given the position of authority of the institution - the possible reading was more problematic. What from a postmodern perspective might be read as irony or ambiguity becomes, from a postcolonial one, evasion. ${ }^{140}$ To go one step further, for those, like the Coalition, seeking the "Truth about Africa," ambiguity within an institution associated with cultural and educational authority itself makes a kind of truth claim. In the face of the Coalition's tactical desire for what might be called an emancipatory metanarrative articulated from a position of strategic essentialism, ${ }^{141}$ the institution (in press releases) fell back on very modern assertions of historical accuracy and curatorial expertise, thereby arguably undermining even the exhibition's postmodern deconstructive intentions.

However, it must also be said that, for this visitor, those intentions were not always consistently realized in the exhibition itself. The curator may indeed have believed that museums are fictional in nature, that "the meaning of their collection is generated in the interaction between the curator, the object, and the visitor." 142 But both within the structure of the exhibit and in the response to the protests, this particular museum did not live up to its definition as a 'negotiated' reality. There was none of the postmodern dialogic museum mode ${ }^{143}$ that postmodern theorists have argued should replace the impersonal, objective, distanced observer-model of modernity: there was no answering African voice in Into the Heart of Africa. While implicitly acknowledging that, in theory, 'culture' is indeed relational, "an inscription of communicative processes that exist, historically, between subjects in relations of power,"144 the exhibit nevertheless never let the other side be heard. One did hear the interaction between the museum officials of 1989 and the collectors of a century before, ${ }^{145}$ but none at all with the Africans whose objects are presented. This was ethnography ("in which European metropolitan subjects present to themselves their others [usually

Material History Review 41 (Spring 1995) / Revue d'histoire de la culture matérielle 41 (printemps 1995) 
their conquered others]") and not 'autoethnography' ("in which people undertake to describe themselves in ways that engage with representations others have made of them"). ${ }^{146}$

Given the complex public stands taken by both sides on this issue of voice, more communication took place, on this occasion, through the press than face to face. Both the Coalition and the museum implicitly acknowledged, in different ways, that communication always involves political interaction and thus power differences. ${ }^{147}$ It is this postmodern truism that has led museological theory to advocate more community consultation and dialogue in the mounting of exhibitions. ${ }^{148} \mathrm{In}$ Canada, by 1989, this had become particularly relevant in the wake of the controversy over the boycott by the Lubicon Lake First Nations of the Native art exhibition, The Spirit Sings, at the Glenbow Gallery during the 1988 Calgary Olympics. ${ }^{149}$ There have now been many recognized examples of more successful dialogue, however. ${ }^{150}$ For instance, a small gallery, the Valentine Museum in Richmond, Virginia, did consult with its community to discover what people felt they needed to learn about their past. One result, in the same year as Into the Heart of Africa, was Jim Crow: Racism and Reaction in the New South. Unlike the ironic (postmodern) Canadian exhibition, this one was frequently confrontational and even unpleasant in its (postcolonial) facing of racist attitudes. ${ }^{151}$

Museums are finding other reflexive ways to deal with both the postmodern and postcolonial implications of collecting and exhibiting. Having been given 100 pieces of African art from a private collection, the University of British Columbia Museum of Anthropology mounted a show in 1991 entitled Fragments, the premise of which was that it is "neither possible nor ethical, in the 1990s, to exhibit Africa; what we can and do exhibit in Fragments are historic African objects valued by a Canadian museum and a Canadian collector." 152 In a postmodern challenge to the modern anonymous, expert narrative voice of labels and text, this exhibit offered instead a plurality of voices and perspectives on the care, handling, and collecting of African objects, as well as on Africa itself. In a more confrontational postcolonial vein, African American artist Fred Wilson mounted The Other Museum, an overt and bold critique of colonialism, stereotyping and racial misrepresentation. Visitors were given a brochure upon entering the gallery that explained this intention to expose prejudices and even announced how irony would be used to label objects and parody the presentation of a natural history museum. In addition, the brochure's style was itself a parody of a National Geographic magazine, and, at the entrance to the displays, an inverted map of the world signalled the entry into the realm of ironic inversion. The technique may at times have been rather obvious - Dan and Ibo masks were blind-folded and gagged with imperial flags but there was little chance of mistaking the artist's intent. ${ }^{153}$ It is also the case, however, that this exhibit was considered as art and viewed in an art gallery, not ethnography presented in a museum: visitors' expectations about postmodern, politicized art exhibitions are never the same as those about anthropological or historical ones.

It is not as if television and film have not represented images of imperialist conquest of Africans for years and in ways much more offensive than Into the Heart of Africa with its reflexivity and indirection. But part of the heritage of modernity is that museums are places of special authority and respect, and therefore have special cultural responsibilities that come with their institutional positions of cultural and educational power within the communities in which they exist. No single postmodern exhibit is going to change this situation overnight, no matter how powerful its critique and deconstruction. If museums really are "historical-cultural theaters of memory,"154 then more than institutional memory will have to be dramatized on their stages. In deciding not to focus the Royal Ontario Museum exhibit on Africa itself, but on the Canadian emissaries of Empire who journeyed "into the heart of Africa," the curator, one might argue, was actually being careful to avoid appropriation and to stay within the boundaries of her unavoidably white Canadian point of view. Yet, in some eyes, she managed to perpetuate the very situation she sought to critique, offering yet another example of the colonizing gaze. Yet, silence about the collection's imperial origins was likely not the answer either. It seems to have been this choice of one single focalization that provoked much of the controversy. An American African Studies professor, Molefi Asante, is said to have compared the choice here to presenting the Holocaust from the viewpont of the Nazis. ${ }^{155}$ There is no doubt that many felt that those once subjected to the gaze of Empire should have been given a voice. 
As Michael Baxandall once argued, "exhibitors cannot represent cultures. Exhibitors can be tactful but stimulating impresarios, but exhibition is a social occasion involving at least three active terms" - makers of objects, exhibitors of those objects, and viewers. ${ }^{156}$

The "Epilogue" to the exhibition catalogue reads with a sad irony in the aftermath of this initial decision about focalization:

By studying the museum as an artifact, reading collections as cultural texts, and discovering the life histories of objects, it has become possible to understand something of the complexities of cross-cultural encounters. In the same process, the intricacies of different cultural configurations are revealed in objects through which various African peoples have expressed not only their individual artistry but also their deepest communal concerns. Finally, by placing in context the relationships, however brief, problematic, and painful, that developed as Canadian soldiers and missionaries travelled into the heart of Africa, it has become clear that the past is part of the present. ${ }^{157}$

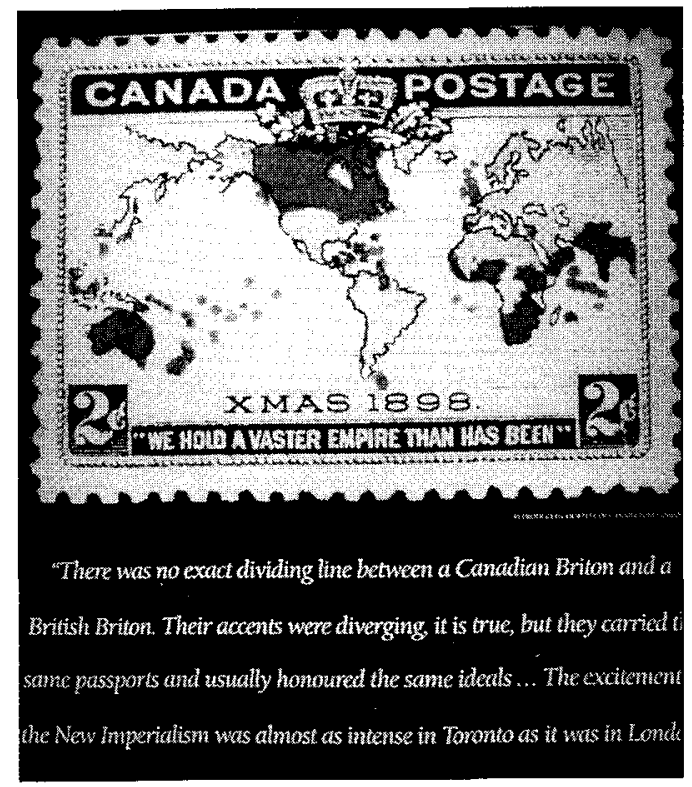

When a Canadian reviewer began her analysis with the words, "We consider ourselves a former colony, not a colonizing power," 158 she put her finger on how difficult it was for some members of the white, English Canadian community to see that past as "part of the present." According to the Coalition, black Canadians had no trouble at all seeing the continuity; nor might Irish, Scots, Native or other Canadians. The curator intended (white?) Canadians to be "horrified by the Canadian participation in this history. Remember that until fairly recently, Canada was a part of the British Empire and participated fully in all aspects of it, including negative ones." 159 The exhibit certainly did place British Canadians (and Torontonians) right in the middle of Empire, citing James Morris's Pax Britannica about 1897: "Hundreds of thousands of British Canadians regarded the imperial saga as part of their own national heritage. The excitement of the New Imperialism was almost as intense in Toronto as it was in London"160 (Fig. 3).

To turn that around, today, the excitement of the new postcolonial critique is equally intense in Toronto (or in Canada as a whole) as elsewhere in the once colonized world, and perhaps for that very reason, there are times when a reflexive, ironic, postmodern challenge is just not strong enough - no matter how demystificatory it might be of modernity's assumptions and even if there were not internal inconsistencies and difficulties. ${ }^{161}$ For Canadians - of all races - today, identity is even more than ever something to be seen, in Clifford's words, "not as an archaic survival but as an ongoing process, politically contested and historically unfinished." 162 When the post rings this time, the message delivered will be positional, and therefore inevitably transitional. ${ }^{163}$ But there will be no returning it to sender. ${ }^{164}$

\section{NOTES}

1. This is the title of the book edited by Ian Adam and Helen Tiffin: Past the Last Post: Theorizing PostColonialism and Post-Modernism (Calgary: University of Calgary Press, 1990).

2. Stephen Toulmin, Cosmopolis: The Hidden Agenda of Modernity (New York: Free Press, 1990), 35.

3. The most oft cited (and brief) statement of Habermas's position is to be found in "Modernity - An Incomplete
Project," in Hal Foster, ed., The Anti-Aesthetic: Essays on Postmodern Culture (Port Townsend, Wash.: Bay Press, 1983), 3-15.

4. Zygmunt Bauman, Intimations of Postmodernity (New York and London: Routledge, 1992), xiv.

5. Eilean Hooper-Greenhill, "Counting Visitors or Visitors Who Count?" in Robert Lumley, ed., The Museum
Fig. 3

Canadian stamp and explanatory panel from Into the Heart of Africa exhibit, 1989-90, Royal Ontario Museum, Toronto, Canada. (Courtesy Royal Ontario Museum) 
Time Machine: Putting Cultures on Display (London: Routledge, 1988), 224.

6. Hooper-Greenhill, "Counting Visitors," 225. Museums, even more than universities, perhaps, reinforce this effect by their architecture - imposing in size, age, dignity - and by the presence of security personnel.

7. On museums, see Ludmilla Jordanova, "Objects of Knowledge: A Historical Perspective on Museums," in Peter Vergo, ed., The New Museology (London: Reaktion Press, 1989), 22.

8. Some exhibits have, in fact, been quite radical in their reflexivity: for example, the Ashmolean's ?Exhibition? (also known as "The Curator's Egg"). See "Destruction or Demolition?" in Museums Journal (December 1992): 20-21.

9. See Spencer R. Crew and James E. Sims, "Locating Authenticity: Fragments of a Dialogue," in Exhibiting Cultures: The Poetics and Politics of Museum Display, ed. Stephen D. Lavine and Ivan Karp (Washington: Smithsonian Institution Press, 1991), 159-75.

10. See, for instance, Norman Palmer, "Museums and Cultural Property," in Vergo, New Museology, 172-204.

11. See, for example, Nicholas Thomas, Entangled Objects: Exchange, Material Culture, and Colonialism in the Pacific (Cambridge, Mass.: Harvard University Press, 1991). For a more extended bibliography of work on Western colonialera and contemporary representations of the 'other' in museum displays, see Mary Jo Arnoldi, "A Distorted Mirror: The Exhibition of the Herbert Ward Collection of Africana," in Museums and Communities: The Politics of Public Culture, ed. Ivan Karp, Christine Mullen Kreamer, and Steven D. Lavine (Washington: Smithsonian Institution Press, 1992), 454-5, note 2.

12. Brian Durrans, "The Future of the Other: Changing Cultures on Display in Ethnographic Museums," in Lumley, Museum Time Machine, 155.

13. Charles Saumarez Smith, "Museums, Artefacts, and Meanings," in Vergo, New Museology, 17.

14. Ibid., 19.

15. Philip Fisher, Making and Effacing Art: Modern American Art in a Culture of Museums (New York: Oxford University Press, 1991), 95.

16. Smith, "Museums," 17.

17. Clifford Geertz, Local Knowledge: Further Essays in Interpretive Anthropology (New York: Basic Books, 1983). See also his The Interpretation of Cultures (New York: Basic Books, 1973). More recently, see Vincent Crapanzano, Hermes' Dilemma and Hamlet's Desire: On the Epistemology of Interpretation (Cambridge, Mass.: Harvard University Press, 1992).

18. James Clifford, "Introduction: Partial Truths," in James Clifford and George E. Marcus, eds., Writing Culture: The Poetics and Politics of Ethnography (Berkeley: University of California Press, 1986), 2.

19. Ibid., 10

20. Talal Asad, "Introduction" to his edition of Anthropology and the Colonial Encounter (New York: Humanities Press, 1973), 16.

21. Cornel West, "The New Cultural Politics of Difference," in Russell Ferguson, Martha Gever, Trinh T. Minh-ha, Cornel West, eds., Out There: Marginalization and Contemporary Culture (New York: New Museum of Contemporary Art; Cambridge, Mass.: MIT Press, 1990), 19.

22. See Smith, "Museums," 19.
23. Stephen E. Weil, Rethinking the Museum and Other Meditations (Washington and London: Smithsonian Institute Press, 1990), xiv.

24. See, for instance, Elaine Heumann Gurian, "Noodling Around with Exhibition Opportunities," in Exhibiting Cultures, 176-90.

25. Durrans, "Future of the Other," 150.

26. Throughout, I will refer to Jeanne Cannizzo as "the curator" in order to put the emphasis on her institutional role and, implicitly, to remind the reader that curators do not work alone, but in conjunction with both museum administration and technical, design, and educational workers in the institution. I do not wish to downplay her personal role (or the consequences of the controversy); I do want to contextualize it, however. There appears to have been a split between intellectual intentions and institutional constraints and traditions. Naming her by her position will allow me to stress this point of conflict.

27. Donald Horne, The Great Museum: The Re-presentation of History (London: Pluto Press, 1984), 222.

28. John McNeill, then acting director, in the Globe and Mail, 21 September 1990, p. C9. The director at the actual time of the exhibit was Cuyler Young.

29. Marlene Nourbese Philip, Toronto Star, 14 January 1991, p. A4.

30. Since 1971, Canada has had an official government policy of 'multiculturalism'; in 1988 the "Act for the Preservation and Enhancement of Multiculturalism in Canada" was passed. The term has always been accepted as a description of the demographic realities of Canada, but the policy and law have been seen in different ways. Some view it still as a federal government ploy to divert attention from Quebec separatist energies; others accuse it of assimilationist aims. The word and policy certainly gained currency when Canada's unofficial selfimage as a northern nation was being challenged from within by the immigration of people from southern European and non-white nations, largely those of the British Commonwealth. The law has been called custodial, paternalistic, anachronistic, reductive, retentive; it has been said to create an enforced inclusiveness and a kind of ethnicity industry. But its defenders argue that, as an ideal of civic tolerance, it has liberal and liberating possibilities. It makes room for diversity and specificity as the defining characteristics of a nation that seems to feel it is in need of self-definition.

31. Robert Lumley, "Introduction" to Lumley, ed., The Museum Time Machine, 2.

32. Robert Stam and Louise Spence, "Colonialism, Racism and Representation," Screen 24, no. 2 (1983): 4.

33. Edward W. Said, "Representing the Colonized: Anthropology's Interlocutors," Critical Inquiry 15, no. 2 (1989): 207. See also his Culture and Imperialism (New York: Knopf, 1993).

34. See, for instance, Gayatri Chakravorty Spivak, The Postcolonial Critic: Interviews, Strategies, Dialogues, ed. Sarah Harasym (New York and London: Routledge, 1990), 49, 62, 103, 163; Laura E. Donaldson, Decolonizing Feminisms: Race, Gender, and Empire-Building (Chapel Hill: University of North Carolina Press, 1992).

35. To generalize, settler colonies are those in which new arrivals (in Canada's case, from Europe) could be motivated by any number of reasons - from enforced exile to adventure; they often marginalized or exterminated 
the indigenous populations, rather than merging with them; they transplanted and intemalized (while deracinating) old world culture and traditions, including language, of course.

36. See Helen Tiffin, "Commonwealth Literature: Comparison and Judgement," in Dieter Riemenschneider, ed, The History and Historiography of Commonwealth Literature (Tubingen: Gunther Narr, 1983), 19-35; Diana Brydon, "The Myths that Write Us: Decolonising the Mind," Commonwealth 10, no. 1 (1987): 1-14. For a theory of the inevitable hybridity of the postcolonial, however, see Bill Ashcroft, Gareth Griffiths, Helen Tiffin, The Empire Writes Back: Theory and Practice in Post-Colonial Literatures (London and New York: Routledge, 1989).

37. Stephen Slemon, "Modernism's Last Post," in Adam and Tiffin, ed., Past the Last Post, 3.

38. Among these is the relation settler colonies have with their aboriginal peoples, of course. In addition, each settler colony, like each forcibly colonized nation, has its own history that cannot be ignored. As the example of the U.S. and Canada reveals, it also matters whether a nation has fought for political independence or has evolved a form of government out of imperial institutions: breaks and ruptures force an articulation of difference and enable the creation of a discourse of identity. This may explain why Canada perpetually lives out its identity crisis.

39. Vijay Mishra and Bob Hodge, "What Is Post(-)colonialism?" Textual Practice 5, no. 3 (1991): 408.

40. Slemon, "Modernism's Lost Past," 3; see also Tiffin, "Commonwealth Literature," 31.

41. One way to state the difference here is to see it as being the difference between being considered (or considering yourself) "inferior" by metropolitan standards because your "official" culture is generally seen as continuous with and derivative of Empire's, and doing so because your indigenous culture is radically different from that of the imperial power (and thus suppressed). My thanks to Shirley Neuman for this concise and cogent articulation of the distinction.

42. I am bracketing here Canada's problematic and likely neo-colonial relationship with the United States, a nation whose cultural, political and economic hegemony and whose relation to multinational capitalism have rendered it one of the new imperial nations of the world. On this point, see René Jara and Nicholas Spadaccini, "Introduction: Allegorizing the New World," in their edition of 1492 1992: Re/Discovering Colonial Writing (Minneapolis: University of Minnesota Press, 1989), 10.

43. Kwame Anthony Appiah, "Is the Post- in Postmodernism the Post- in Postcolonial?" Critical Inquiry 17, no. 2 (1991): 348 .

44. Albert Memmi, The Colonizer and the Colonized, trans. Howard Greenfeld (New York: Orion Press, 1965), 89.

45. Abdul R. JanMohamed, Manichean Aesthetics: The Politics of Literature in Colonial Africa (Amherst: University of Massachusetts Press, 1983), 4-5. See too Homi Bhabha's discussion of the double role of the colonizer, "'in double duty bound,' at once civilizing mission and a violent subjugating force," in "The Other Question: Difference, Discrimination and the Discourse of Colonialism," in Ferguson, et al,, Out There, 71.

46. Richard Terdiman, Discourse/Counter-Discourse: The Theory and Practice of Symbolic Resistance in Nineteenth-Century France (Ithaca, N.Y.: Cornell
University Press, 1985). The subsequent citations are from pp. 76-7.

47. Irony, of course, is a transideological trope: it can be used to legitimate but also to undermine a whole range of ideological positions. It can be democratic; it can be elitist. As Susan Purdie remarks about jokers, ironists too can be seen to constitute themselves as discursively powerful. See her Comedy: The Mastery of Discourse (Toronto: University of Toronto Press, 1993), 128-49. On the specifically Canadian use of oppositional ironies, see Linda Hutcheon, Splitting Images: Contemporary Canadian Ironies (Toronto: Oxford University Press, 1991).

48. See, for example, in The New Museology: Smith, "Museums," 20; Jordanova, "Objects of Knowledge," 40; Philip Wright, "The Quality of Visitors" Experiences in Art Museums," 136-7. Elsewhere, see Weil, Rethinking the Museum, 52.

49. The counter position is that of Fredric Jameson who argues that "it is high time to abandon" the concepts of irony and reflexivity as being of any use. See his Modernism and Imperialism (Derry: Field Day Theatre Co. Pamphlet \#14, 1988), 64.

50. See Lumley, Museum Time Machine, 13.

51. For example, see Paul Greenhalgh, "Education, Entertainment and Politics: Lessons from the Great International Exhibitions," in Vergo, The New Museology, 95: "museums are an intensely political phenomenon and we should acknowledge this fact with panache and honesty."

52. Durrans, "Future of the Other," 162.

53. See Gill Seidel, "We Condemn Apartheit, BUT...': A Discursive Analysis of the European Parliamentary Debate on Sanctions (July 1986)", in Ralph Gillo, ed., Social Anthropology and the Politics of Language (London: Routledge, 1989], 230.

54. For some commentators, for example, postmodern deconstructive ways of thinking were deemed not yet part of the consciousness of the general public - though the increasing reflexivity of even television programming might contest such a view. See Enid Schildkrout, "Ambiguous Messages and Ironic Twists: Into the Heart of Africa and The Other Museum," Museum Anthropology 15, no. 2 (1991): 17.

55. See Marianna Torgovnick, "Traveling with Conrad," in her Gone Primitive: Savage Intellects, Modem Lives (Chicago: University of Chicago Press, 1990), 141-58.

56. According to the curator, Jeanne Cannizzo, writing after the fact, the title was also meant to signal that the exhibition would deal "with the past, with journeys, interaction and the disjunction between Canadian images and African realities." See her "Exhibiting Cultures: Into the Heart of Africa, "Visual Anthropology Review 7, no. 1 (1991): 151-2.

57. From a public letter of apology for the offence "felt by some," written over six months after the close of the exhibition (issued on 1 March 1991).

58. Cannizzo, "Exhibiting Cultures," 150.

59. As Cannizzo explained to the Toronto Stor, 5 June 1990

60. Cannizzo, "Exhibiting Cultures," 151.

61. Fisher, "Making and Effacing Art," 96

62. Brochure handed out by members of the Coalition picketing in front of the museum.

63. Hazel A. Da Breo, "Royal Spoils: The Museum Confronts its Colonial Past," Fuse, 13 (Winter 1989-90): 33. 
64. In the context of the Canadian debates over 'appropriation of voice', Cannizzo rightly noted that at least the exhibit did not appropriate the black voice ("Exhibiting Cultures," 152). That it also silenced that voice is not discussed, however.

65. Though the director of the museum and, especially, the curator took most of the pressure, it is worth reminding ourselves once again that there was a team involved in creating this (like any other) show: in addition to the curator, there was a graphic designer, an architect, an artist, and an interpretive planner. Since, as we shall see, display involves design as much as conceptual framing, many of the problems could not be directly attributed to the curator alone.

66. Cannizzo, "Exhibiting Cultures," 152.

67. Ibid., 153.

68. See Jordanova, “Objects of Knowledge," 32 , on how trophies from colonial expansion in museums usually express "victory, ownership, control and dominion" which trigger "fantasies and memories" and elicit admiration.

69. Cannizzo, "Exhibiting Cultures," 157: the intention was to expose "a rather brutal historical reality" and make "clear that the imperial advance was not some sort of adventure story but resulted in death and destruction."

70. Even in book or magazine illustrations, advertising, or illustrated dictionaries, there is always a complicated verbal/visual tension between the decorative and the didactic, between the descriptive and the prescriptive.

71. See Schildkrout, "Ambiguous Messages," 19.

72. Susan Crean, "Taking the Missionary Position," This Magazine 24, no. 6 (February 1991): 26.

73. Cannizzo, "Exhibiting Cultures," 156.

74. Cannizzo, "Exhibiting Cultures," 152.

75. Schildkrout, "Ambiguous Messages," 17.

76. For a summary of the range of responses, see Robert Fulford, "Into the Heart of the Matter," Rotunda (September 1991): 24.

77. Among those who held this view, see Simon Chung, "Into the Heart of ROM's Racism," Lexicon 10 (October 1990): 7.

78. See Errol Nazareth, "Royal Ontario Museum Showcase Showdown," Now (29 March-4 April 1990): 11.

79. Cannizzo, "Exhibiting Cultures," 154, my emphasis.

80. Durrans, "Future of the Other," 145.

81. Heather Robertson, "Out of Africa, Into the Soup," Canadian Forum 69, no. 792 (September 1990): 4; Charles Roach, Toronto Star, 5 June 1990.

82. The word is that of one of the demonstrators, as cited in Toronto Star, 13 June 1990, p. A3.

83. Crean, "Missionary Position," 25.

84. Cited in "Analyzing Racism at ROM" in The Varsity (June 1990): 4.

85. Individual visitors saw other ironies which the evidence of the curator's comments and the catalogue would suggest were not actually intentional ones. For instance, see Schildkrout, "Ambiguous Messages," 21: "In both text and image, the exhibition attempted to use irony in order to present its condemnation of the colonial point of view. In addition to the unfortunate quotations and pseudo-quotations, the exhibition contained section titles that were meant to be read as ironic cues. For example, the ROM assumed (wrongly) that the audience would understand the irony intended in the use of the word 'Commerce' as a title for an exhibit case devoted to artifacts of the slave trade."

86. Handout distributed at the picket lines.

87. Christopher Hume, Toronto Star, 15 May 1990.

88. Cannizzo, "Exhibiting Cultures," 155.

89. Homi K. Bhabha, "Of Mimicry and Man: The Ambivalence of Colonial Discourse," October 28 (1984): 125-33.

90. Bhabha, "The Other Question," 71.

91. See Peter Vergo, "The Reticent Object," in Vergo, The New Museology, 53 on the persistent museological belief that elucidation can only take the form of words.

92. Crean, "Missionary Position," 25.

93. This term was used quite often in the press: see, for example, editorial in the Globe and Mail, 19 October 1990 , p. A16; Bronwyn Drainie in the same newspaper, 24 March 1990.

94. Cf. David Cayley, Globe and Mail, 10 August 1990.

95. Schildkrout, "Ambiguous Messages," 21.

96. Oji Adisa and Ras Rao, cited by Isabel Vincent in the Globe and Mail, 14 July 1990, pp. D1-D2.

97. Eva Mackey, "The Politics of Race and Representation in Toronto, Canada: Events and Discourses Around the Royal Ontario Museum's 'Into the Heart of Africa' Exhibit," (M.A. diss., University of Sussex, 1992), 46-7.

98. This question was raised by Zhao Meichang (1990) in a graduate course paper (Department of English, University of Toronto) entitled "ROM's Into the Heart of Africa: A Commentary."

99. This is the suggestion of Susan Crean, "Missionary Position," 25.

100. Brenda Austin-Smith, "Into the Heart of Irony," Canadian Dimension 27, no. 7 (1990): 52.

101. See the letter to the editor by A. W. Frank Banfield, the son of one of those missionaries, in the Toronto Star, 26 May 1990, p. D3; Isabel Vincent, Globe and Mail, 28 July 1990, p. C12 on William Samarin's defense in Christian Week; cf. Colan Mitchell, letter to editor, Toronto Star, 5 June 1990, p. A16.

102. See Globe and Mail, 20 June 1990.

103. Christopher Hume, Toronto Star, 29 September 1990.

104. Hazel Da Breo, cited in Errol Nazareth, "Royal Ontario Museum Showcase Showdown," Now (29 March4 April 1990): 10-12.

105. Fulford, "Heart of the Matter," 19.

106. Rachel M. Brownstein, "Jane Austen: Irony and Authority," in Regina Barreca, ed., Last Laughs: Perspectives on Women and Comedy (New York: Gordon and Breach, 1988), 57.

107. Delia Chiaro, The Language of Jokes: Analysing Verbal Play (New York and London: Routledge, 1992), 10-14. She also points out that the concept of what people find funny "appears to be surrounded by linguistic, geographical, diachronic, sociocultural and personal boundaries," (p. 5).

108. Here I am referring to Wayne C. Booth's theory in his The Rhetoric of Irony (Chicago: University of Chicago Press, 1974) that irony creates "amiable communities" between ironists and audiences.

109. My reference here is to Booth's famous distinction throughout The Rhetoric of Irony between stable and unstable ironies.

110. Charles Roach, Now (22 March-4 April 1990); Toronto Star, 5 June 1990.

111. Michael Valpy, Globe and Mail, 6 June 1990.

112. Durrans, "Future of the Others," 163. 
113. Smith, "Museums," 19. See too Wright, "Quality of Visitors' Experiences," 133-4.

114. Austin-Smith felt only white audiences could have "access to the luxury of ironic detachment" (p. 52).

115. As discussed by Bronwyn Drainie, Globe and Mail, 24 March 1990 and 6 April 1991. Part of the reason for such a response, as Marlene Nourbese Philip pointed out, is that, for Africans, museums have been seen as "a significant site of their racial oppression" (Toronto Star, 14 January 1991, p. A4).

116. The powerful use of irony by black artists such as Robert Colescott and Fred Wilson (working within the museum setting, as well) would suggest that this view is not shared by all, however.

117. Austin-Smith, "Into the Heart of the Matter," p. 52.

118. Crean, "Missionary Position," 25.

119. Cited in Fulford, "Heart of the Matter," 23.

120. Benedict Anderson, Imagined Communities: Reflections on the Origin and Spread of Nationalism (London: Verso, 1983)

121. Pierre Bourdieu, In Other Words: Essays Towards a Reflexive Sociology (Cambridge: Polity Press, 1990), 130.

122. See Pierre Bourdieu, Distinction (London: Routledge, 1984).

123. Indeed, in "Museum Visiting as a Cultural Phenomenon," in Vergo, ed., The New Museology, Nick Merriman suggests that people who are better off in the present than they were in the past and who visit museums "because of their cultured connotations, as a way of legitimating their higher status with an appropriate leisure activity" (p. 170) are more likely to have a negative view of the past, "seeing it as something we have progressed from, as a way of legitimating their present status" (p. 170).

124. Interestingly, age and gender are usually considered to be less significant differences.

125. Hooper-Greenhill, "Counting Visitors," 215

126. Eva Mackey described herself as the "perfect" viewer of the exhibit: a student of anthropology, with a grounding in reflexive, postmodern anthropology and feminism, and therefore interested in how "meaning about "others' is constructed," she had also done research on the white colonial presence in Africa and was part of the white, anglophone majority of Canada ("Politics of Race,"p. 7).

127. Unlike the situation in the United States, there was historically a much smaller black slave population in Canada; some Canadian blacks came as loyalists at the time of American independance or as travelers on the Underground Railroad. In Toronto today, there are many black communities originating from various Caribbean islands and African nations, most recently Somalia.

128. Cannizzo, "Exhibiting Cultures," 154.

129. Cf. Donna Laframboise, Toronto Star, 22 October 1990.

130. Schildkrout, "Ambiguous Messages," 20: "Despite disclaimers that these people were speaking in the context of another epoch, the overall impression given to many visitors was that the ROM endorsed their views."

131. James Clifford, "On Collecting Art and Culture," in Ferguson, et al., Out There, 144.

132. Ibid., 144. Toronto writer Margaret Atwood has presented, in both poems (such as "Elegy for the Giant Tortoises" and "A Night in the Royal Ontario Museum") and fiction - most notably, in Life Before Man - a view of the project of modernity institutionalized specifically in the ROM. The fictionalizing and constructing power of categorizing, for example, is articulated and critiqued in that novel by a museum paleontologist who feels the urge to cry out to those who have faith in that institution's facts and definitions: "The Mesozoic isn't real. It's only a word for a place you can't go to any more because it isn't there. It's called the Mesozoic because we call it that" (Toronto: McClelland and Stewart, 1979), p. 290, italics hers.

133. Jeanne Cannizzo, exhibit catalogue, Into the Heart of Africa (Toronto, 1989), p. 62. Subsequent references will be in parentheses in the text itself.

134. James Clifford, The Predicament of Culture: TwentiethCentury Ethnography, Literature, and Art (Cambridge, Mass.: Harvard University Press, 1988), 213.

135. Cannizzo, "Exhibiting Cultures," 155.

136. Ayanna Black, cited in Crean, "Missionary Position," 27.

137. Cannizzo, catalogue, 35.

138. Jim Freedman, "Bringing It All Back Home: A Commentary on Into the Heart of Africa," Museum Quarterly 18, no. 1 (1990): 40.

139. There were, however, critiques of the postmodern strategies of the show as well. See Schildkrout, "Ambiguous Messages," 19: "instead of finding an account of Canadian involvement in the colonization of Africa, the audience got snippets of biographies and general statements that suggested colonial attitudes. The audience is told little about the history and effects of British military exploits in Africa, but is given a powerful hint of exploitation and violence."

140. See Crean, "Missionary Position," 24: the organizers were "awfully quiet and oblique in their disapproval, never directly condemning or examining its legacy."

141. See Eva Mackey, p. 61 (via Lyotard) and Diana Fuss, Essentially Speaking: Feminism, Nature, and Difference (London and New York: Routledge, 1989), 105-7 especially. See also Clifford, Predicament, 12: "If authenticity is relational, there can be no essence except as a political, cultural invention, a local tactic."

142. Cannizzo, "Exhibiting Cultures," 151.

143. See John Kuo Wei Tchen, "Creating a Dialogic Museum: The Chinatown History Museum Experiment," in Museums and Communities, 285-326.

144. James Clifford, "On Ethnographic Allegory" in Clifford and Marcus, Writing Culture, 15.

145. Cannizzo, "Exhibiting Cultures," 156: "period quotations and historical photographs were used to suggest interaction, the process of collection and the presence of individuals behind the objects."

146. Mary Louse Pratt, "Arts of the Contact Zone," Profession 91, 35. See too bell hooks, Yearning: Race, Gender and Cultural Politics (Boston: South End Press, 1990), 150-2 on 'radical critical thinkers' describing the 'other'

147. See Barbara Herrnstein Smith, Contingencies of Value: Alternative Perspectives for Critical Theory (Cambridge, Mass.: Harvard University Press, 1988), 102: "Communication is...a political interaction, not only in that its dynamics may operate through differences of power between the agents but also in that the interaction may put those differences at stake, threatening or promising (again it must cut both ways) either to confirm and maintain them or to subvert or otherwise change them." See too Donna Haraway, Simians, Cyborgs, and Women: The Reinvention of Nature (New York: Routledge, 1991), 163 on the "informatics of domination." 
148. The difficulties with consultation began with the multiple and fragmented African Canadian communities in the city - of West Indian, African, and American/Canadian origins. The museum did have its promotional, publicity and educational material screened for possible problems by paid experts from the black community; it introduced the show five months before its opening at a reception for that community and, subsequent to a negative response at this stage, set up focus groups and made changes to some of the promotional material though not, I believe, to the show itself. An expert in African anthropology vetted the catalogue. Lectures and other events were set up by a black African historian, Dr. Kasozi, in conjunction with the exhibition. Some of these were later cancelled because of lack of attendance (after the demonstrations began).

149. This led to a "Task Force on Museums and First Peoples" whose 1992 report was introduced by a letter from Ovide Mercredi, National Chief of the Assembly of First Nations: "Out of controversy can come understanding and an opening for constructive dialogue. The Assembly of First Nations is pleased to have been involved in the Task Force on Museums and First Peoples. The many cultures of the peoples of Canada have so much to share with each other. Out of this sharing can only come a renewed pride in their respective cultures."

150. For a discussion of the successful "Art/artifact" exhibition, see Steven D. Lavine and Ivan Karp, "Introduction: Museums and Multiculturalism," in Exhibiting Cultures, 7-8. In the same volume, the curator of that exhibit describes her intention: see Susan Vogel, "Always True to the Object," 191-204.

151. Not every postcolonial exhibit has been well received, of course. The Smithsonian's 1991 West as America showed how some nineteenth-century artists glorified the European conquest of the Americas, downplaying exploitation, genocide, cultural displacement, and greed, while representing the indigenous pooples as fierce, brutal, and thus worthy of suppression. The museums planning to host the show after the Washington opening backed out in the face of negative response from the American public. This was also the fate of Into the Heart of Africa: the four American and Canadian museums which had agreed to present the show cancelled after the Toronto protests.

152. Marjorie Halpin, "Fragments: Reflections on Collecting," University of British Columbia Museum of Anthropology Museum Note 31 (1991), p. 2.

153. See Schildkrout, "Ambiguous Message," 22: "Wilson's agenda was straightforward, cleverly presented, and unambiguous."

154. Clifford, "On Collecting," 164

155. Cited by Ahmed Elamin, Share, 4 April 1991, p. 1.

156. Michael Baxandall, "Exhibiting Intention: Some Preconditions for the Visual Display of Culturally Purposeful Objects," in Exhibiting Cultures, 41.

157. Cannizzo, catalogue, 92.
158. Adele Freedman, Globe and Mail, 17 November 1989, p. C11.

159. Cannizzo, in an interview with Hazel Da Breo in Fuse 13 (Winter 1989-90), 37. See Jane Peirson Jones, "The Colonial Legacy and the Community: The Gallery 33 Project," in Museums and Communities, 221-41. Jones is the curator of the Gallery 33 project at the Birmingham Museum and Art Gallery and describes the success of this exhibition space in terms relevant to the ROM controversy: "Gallery 33 re-presents the museum's ethnography collection and reflects the heritages of local ethnic minority communities. At the same time it is an exhibition about cultural diversity. But the focus on collectors and collecting achieves several additional goals: deconstructing colonialism, recontextualizing twentiethcentury migrations, and integrating the histories of white Britons and ethnic minorities. In doing so, Gallery 33 moves forward and becomes more than an essay in cultural diversity: it begins to inform and challenge all of Birmingham's communities" (p. 240).

160. Cited both in the exhibition and in Cannizzo, catalogue, 14.

161. With the notoriously fine vision of hindsight and admittedly not taking into account the difficulties of timing and of institutional constraints, it is (perhaps too) easy to suggest a number of design and framing changes that might have been made to the exhibition even after it opened: reducing the size of certain violent visual images; being more clear and consistent about the function of quotation marks; perhaps choosing to rely less on ironic indirection; reducing the necessity of having to read texts to get meaning; being more aware of the power and semiotic coding of visual images; removing the African "boutique" and its white staff; even inverting the order of the exhibition - introducing the objects in their African context first, then tracing how they came to enter the museum's collection.

162. Clifford, Predicament, 9.

163. This connection is that of Trinh Minh-ha in When the Moon Waxes Red: Representation, Gender and Cultural Politics (London and New York: Routledge, 1991), 2.

164. I would like to express my thanks to all those who helped me, in their various ways, to think through the many issues raised by this controversial exhibition: the W.I.P.E. group, Melba Cuddy-Keane, Chandler Davis, Rebecca Duclos, Len Findlay, Marjorie Halpin, Adrienne Hood, Michael Hutcheon, Eva-Marie Kröller, Michael Levin, Eva Mackey, Shirley Neuman, Alan J. Ryan, Hayden White, Zhao Meichang, and the stimulating graduate students and faculty of the Museum Studies program at the University of Toronto. A special thanks is due to all the participants in the 1990 seminar on the discursive politics of irony at the International Summer Institute for Structuralist and Semiotic Studies, Victoria College, University of Toronto. This seminar took place in June of 1990 - as the demonstrators picketed across the street at the Royal Ontario Museum. 